DOI: $10.22616 /$ j.balticsurveying.2018.015

\title{
LEGITIMATION OF "SPECIAL VALUE" AS A TOOL OF LEGAL PROTECTION OF LANDS: THE CASE OF UKRAINE
}

\author{
Taras Ievsiukov \\ National University of Life and Environmental Sciences of Ukraine
}

\begin{abstract}
The main factors that influence the rational land use, conservation and protection of land resources are global ecological and food security, world's population growth, climate change, land acquisition by large world agricultural corporations etc. In this process a priority of attention is protection of the important agricultural lands (in Ukraine, these lands are called especially valuable lands - EVL). Besides, lands with highly productive soils, areas with undisturbed ecosystems, territories with objects of cultural heritage, natural therapeutic resources are a part of EVL. This paper focuses on new approaches to the legal protection of EVL in Ukraine. The special value of these lands in Ukraine is legalized and is means of their legal protection (Art. 150 of the Land Code of Ukraine).

The main idea of this paper - studying of problems of legal protection of EVL and development of new approaches to their protection. These approaches will be based on introduction of economic regulators at withdrawal of EVL or change their intended use for needs that don't correspond to nature protection value.

The reseach is based on case study method and statistical method. Approaches for cartographic modeling for assessment and mapping of EVL are offered.

Results of this reseach are an obtaining of practical experience in the field of protection of EVL in Ukraine, development of suggestions for improving of an organizational and legal mechanism the use of EVL through their registration, monitoring, evaluation, development of their State Register. These measures can increase competitiveness of EVL, prevent Land-Grabbing and provide sustainable development of the rural territory. Key words: especially valuable lands, special value, legal protection, land, important agricultural lands.
\end{abstract}

\section{Introduction}

In the 21 st century, many countries in the world implement a rigorous policy of preserving the capacity of arable land while simultaneously intensive use. The main reasons for introducing such land policy are: 1) aggravation of the global food crisis, deepening of geopolitical, environmental problems, loss of productive lands as a result of negative human activity and the growth of the global deficit of agricultural land, which leads to the global scale of their accumulation by world financial corporations, and in some cases states ("land grabbing"); 2) unsystematic urbanization and transformational processes in the agrarian sector and, as a result, dynamic changes in land use; 3) the key role of productive lands in ensuring sustainable social and economic development of society; 4) the need to introduce new effective barriers to the conservation of high-yielding lands, valuable natural components, objects of historical and cultural heritage; 5) lack information regarding the proliferation of productive lands, parameters of their condition and land use; 6) the need to provide state authorities and local self-government, interested in enterprises' and institutions and citizens with information on land availability.

The most valuable lands play a important role in ensuring stable social-economic development in growing global threats to human development. In countries such as Greece, China, Germany, the USA, France and others, there are examples of the allocation of special value land as the basis for maintaining their uniqueness or high productivity. Such land include to the national registers, which is a serious barrier when withdrawing them for non-agricultural needs (K. Hennenberg et. al., 2008; P. Pointereau et. al., 2007). P. Loiko (2009) study of valuable high-yielding agricultural lands with the aim of their protection. At the level of administrative-territorial units, these approaches are deepened O.Golodnaya and N. Kostenkov. The scientists have developed proposals for the allocation of particularly important and valuable agricultural lands and the establishment of boundaries of these territories in order to create a special regime for their use (2010). Examples of studies of landresource capacity of a whole Ukraine and its regions, administrative and natural geographic regions may serve as a researches of S. Doroguntsov, V. Rudenko, M. Hvesyk. Concentrated their attention on 
the study of the problems of land use and land protection D. Babmindra, D. Dobryak, O. Kanash, A. Martyn, L. Nowakowskiy, A. Tretiak, M. Fedorov.

It should be noted that the relevance of this paper focuses on approaches to the legal protection of especially valuable lands (EVL) in Ukraine. This paper is study of the problems of legal protection of EVL and development of new approaches to their protection. These approaches will be based on the introduction of economic regulators in the seizure of EVL or changing their intended use for needs that don't meet the conservation value.

\section{Methodology of research and materials}

The main research methods were the following: statistical (when processing the results), mapping (during development and conclusion of cartographic models (maps) that displays available spatial information on the distribution of EVL and their evaluation, and their subsequent processing methods mathematical and cartographic modeling will provide a new (original) information). The materials for research were data from the State Service of Ukraine for Geodesy, Cartography and Cadastre. In particular, we used statistical information on quantitative land accounting, land evaluation materials and other data.

\section{Discussions and results}

Ukraine is one of the largest countries in Europe, its area is 60,4 million hectares. More than $53,6 \%$ (32,4 million hectares) of the Ukrainian territory is used for arable farming. About $1 / 3$ of the arable land has such characteristics as to which these lands are classified as EVL.

They are the most valuable part of a national wealth of Ukraine. EVL concentrate in itself as the most productive lands available for natural and acquired properties, and can generate high yields of crops, the environment, recreational area; lands wich are subject of researches in the long-term, lands of historical and cultural significance etc.

In Ukraine the "special value" of these lands is legitimized at the state level and is tool of their protection. Thus, this is the main mechanism for the legal protection of EVL. Author's classification of legal protection of EVL includes the following types:

1. Especially valuable productive soils on agricultural land. Their area is 11950.65 thousand hectares (19.8\% of the territory of Ukraine). They divided on especially valuable soils national level, especially valuable regional soils (http://zakon1.rada.gov.ua/laws/show/z0979-03).

This model allows us to include in the first group are EVL, which are determined by the highest fertility within all countries, despite their geographic location. That is their productive potential and it is highly compared to other soils. The second group includes soils that are the quality indicators. They are the most fertile in a particular region (appropriate single out in the context of natural agricultural provinces), but in other areas can be yield substantially by different productivity in fertile soils (O. Kanash, A. Martyn, 2003). In the development of these approaches at agricultural natural areas may produce locally most valuable soils (O. Kanash, 2009).

The EVL dominate the structure of agricultural land in the Forest-steppe and Steppe areas, where, depending on the province's natural and agricultural province, they make up from $15.0 \%$ (Stepovaya Danubian) to $40.2 \%$ (Steppe arid Left Bank). The estimation of these lands, as well as indicators of quantitative distribution in the regions of Ukraine is presented in Table 1 and Figure 1. 


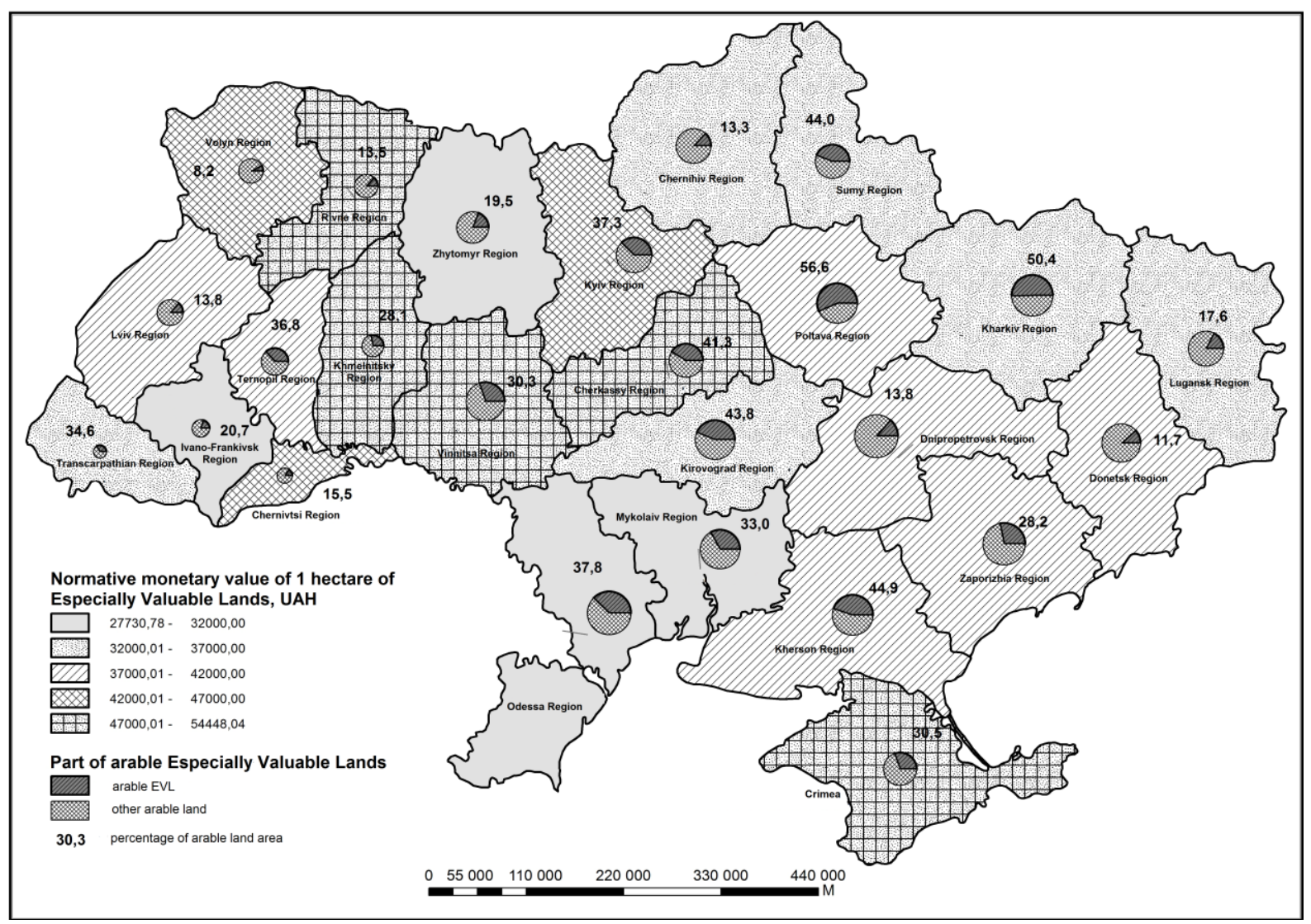

Fig. 1. Normative monetary value and part of arable EVL in the structure of arable land of Ukraine

The cost of EVL is $39.0 \%$ of the total cost of arable land in Ukraine. This is despite the fact that the area of these lands is 9.4 million hectares, or $31.5 \%$ of the total arable land of Ukraine.

2. Lands of nature conservation and other nature conservation purposes. Their area, according to the operational information of the State Service of Ukraine on Geodesy, Cartography and Cadastre, is 3326.4 thousand hectares (5.5\% of the territory of Ukraine), including 655 objects of national level on the area of 1590.6 thousand hectares and 7513 objects of local level on the area of 1735.8 thousand hectares. They are mainly concentrated in Kherson Region (13 objects of national level and 66 local level on the area of 272.7 thousand hectares), Chernihiv Region (22 objects of national level and 633 local level in the area of 240.2 thousand hectares), temporarily occupied by the AR Crimea (44 objects of the national level and 137 local level on the area 178.4 thousand hectares).

The modern structure of the nature reserve fund of Ukraine includes 11 categories of territories and objects of national and local level. About $90 \%$ of all existing objects belong to nature monuments, preserves and protected areas, while up to $80 \%$ of the nature reserve fund is made up of nature reserves, national natural and regional landscape parks.

More than half of the lands of the nature reserve fund of Ukraine include territories and objects of national level, including 17 natural and four biosphere reserves (13.9\% of the total area of the nature reserve fund), 17 national natural parks (25.0\%), 303 nature reserves (12.6\%), 132 natural monuments $(0.2 \%), 17$ botanical gardens, 19 dendrological and seven zoological parks $(0.1 \%), 88$ parkmonuments of garden art $(0.2 \%)$.

3. Lands of historical and cultural purpose occupy a relatively small area -45.9 thousand hectares ( $0.1 \%$ of the territory of Ukraine). However, they accumulate in themselves the vital and aesthetic ideals of past generations and are an important part of the national cultural treasury. At the same time, about 143 thousand immovable cultural heritage sites that require special protection from the state are recorded on the territory of Ukraine. Today one of the important issues is inventory of lands of historical and cultural purpose and registration of rights to use them. 
The cost of arable EVL in the structure of arable land of Ukraine

\begin{tabular}{|c|c|c|c|c|c|c|c|}
\hline \multirow{3}{*}{ Region } & \multicolumn{3}{|c|}{ Arable land area } & \multicolumn{3}{|c|}{$\begin{array}{l}\text { Normative monetary value of } \\
\text { arable land as of 01.01.2016, } \\
\text { UAH / ha }\end{array}$} & \multirow{3}{*}{$\begin{array}{l}\text { Difference in } \\
\text { the cost of } 1 \\
\text { hectare of } \\
\text { arable EVL } \\
\text { and other } \\
\text { arable land, } \\
\text { UAH / ha }\end{array}$} \\
\hline & \multirow[t]{2}{*}{ Total, ha } & \multicolumn{2}{|c|}{ Including EVL } & \multirow{2}{*}{$\begin{array}{c}\text { Arable } \\
\text { land of } \\
\text { the region }\end{array}$} & \multirow{2}{*}{$\begin{array}{c}\text { Arable } \\
\text { EVL }\end{array}$} & \multirow{2}{*}{$\begin{array}{c}\text { Other arable } \\
\text { land } \\
\text { (except EVL) }\end{array}$} & \\
\hline & & ha & $\%$ & & & & \\
\hline Crimea & 1144594 & 348933 & 30,5 & 36947,60 & 47143,84 & 32476,09 & 14667,75 \\
\hline Vinnitsa & 1572768 & 476439 & 30,3 & 33073,42 & 47378,11 & 26856,93 & 20521,18 \\
\hline Volyn region & 623606 & 51149 & 8,2 & 29940,42 & 44428,48 & 28645,91 & 15782,57 \\
\hline Dnipropetrovsk & 1955004 & 270628 & 13,8 & 32525,99 & 37045,07 & 31799,91 & 5245,16 \\
\hline Donetsk & 1568553 & 183691 & 11,7 & 34854,68 & 39730,71 & 34207,91 & 5522,80 \\
\hline Zhytomyr & 1062258 & 207127 & 19,5 & 20580,98 & 31726,66 & 17881,31 & 13845,36 \\
\hline Transcarpathian & 180297 & 62346 & 34,6 & 26377,87 & 36634,77 & 20956,33 & 15678,44 \\
\hline Zaporizhia & 1868442 & 526173 & 28,2 & \begin{tabular}{|l|}
33838,40 \\
\end{tabular} & 41043,92 & 31013,82 & 10030,10 \\
\hline Ivano-Frankivsk & 326606 & 67468 & 20,7 & 28567,62 & 30625,89 & 28031,74 & 2594,15 \\
\hline Kyiv region & 1304213 & 480 & 37,3 & 3197 & & &, 11 \\
\hline Kirovograd & 1641518 & 719250 & 43,8 & 32096,51 & 36170,27 & & 7250,76 \\
\hline Lugansk & 1301940 & 229668 & 17,6 & 26520,22 & 33652,13 & 24992,65 & 3659,48 \\
\hline Lviv & 711164 & 98033 & 13,8 & 26622,12 & 39991,79 & 24484,46 & 15507,33 \\
\hline \begin{tabular}{|l|} 
Mykolaiv \\
\end{tabular} & 1629194 & 536968 & 33,0 & 26361,05 & 27730,78 & 25687,66 & 2043,12 \\
\hline Odessa & 1987976 & 752312 & 37,8 & 28112,83 & 31263,21 & 26194,77 & 5068,44 \\
\hline Poltava & 1691902 & 956851 & 56,6 & 34252,51 & 38682,46 & 28485,83 & 10196,63 \\
\hline Rivne & 571069 & 77086 & 13,5 & 31405,86 & 54448,04 & 27810,13 & 26637,90 \\
\hline Sumy & 1222434 & 537233 & 43,9 & 29426,66 & 35699,23 & 24508,64 & 11190,59 \\
\hline Ternopil & 776136 & 285496 & 36,8 & 30040,16 & 39536,30 & 24514,50 & 15021,81 \\
\hline Kharkiv & 1793876 & 904735 & 50,4 & 32506,62 & 35583,73 & 29375,54 & 6208,20 \\
\hline Kherson & 1727884 & 776288,2 & 44,9 & 34698,86 & 38441,90 & 31645,38 & 6796,51 \\
\hline Khmelnitsky & 499190,9 & 140032,8 & 28,1 & 34496,74 & 48702,21 & 28958,14 & 19744,07 \\
\hline \begin{tabular}{|l|} 
Cherkassy \\
\end{tabular} & 1203120 & 496346 & 41,3 & 39811,13 & 48746,11 & 33536,36 & 15209,75 \\
\hline \begin{tabular}{|l} 
Chernivtsi \\
\end{tabular} & 243793 & 37863 & 15,5 & 33999,84 & 44308,87 & 32104,39 & 12204,48 \\
\hline \begin{tabular}{|l|} 
Chernihiv \\
\end{tabular} & 1264192 & 168533 & 13,3 & 24422,96 & 36088,32 & 22628,61 & 13459,71 \\
\hline Total & 29871730 & 9397129 & 31,5 & 30927,77 & 38340,34 & 27525,66 & 10814,69 \\
\hline
\end{tabular}

Source: made by the author by using the data of the State Service of Ukraine on Geodesy, Cartography and Cadastre (http://land.gov.ua/)

4. The land of experimental fields of research institutions and educational institutions occupy almost 458.7 thousand hectares ( $0.8 \%$ of the territory of Ukraine).

5. The land wich will be included to EVL in the future. These lands include lands of other categories and today their allocation is not provided by law, but in the future it will be possible: forestry purpose (especially protective forest areas, plots with positive trees, etc.); recreational use (territories with unique natural recreational use); health resort (territories with unique natural therapeutic properties); lands of public and residential buildings (land plots of urban development, etc.); water fund (coastal protective strips, land of water protection zone).

On the one hand, as a result of the analysis of the legal basis for the protection of EVL, a high level of their legal protection has been established. Since these lands can be seized solely by the decision of the supreme legislative body of the state - the Verkhovna Rada of Ukraine. On the other hand, the practice of land relations shows a large-scale seizure of EVL without proper procedures.

The priority of agricultural land is fixed in the land legislation of Ukraine (Art. 23 of the Land Code of Ukraine), but on the facts these lands are a reserve for other land use, first of all, housing, public and industrial development. One of the peculiarities of EVL is their placement in plain areas or areas with a slight inclination. If such land is located near the city (village, settlement), the probability of their extraction for non-agricultural use in the future will be very high. 
In the first place, the economic benefits of using land for development will exceed the economic benefits of its agricultural land use. Secondly, the demand for land for development is formed due to the demand for housing and the lack of settlements free of land development. As a result, unbuilt land will be considered as reserve areas to expand the boundaries of settlements. The increase in real incomes of citizens, observed before the financial and economic crisis of 2008 , has contributed to the growth of such demand and, accordingly, the increase in housing prices. As a result, the investment attractiveness of land for development has increased. In the suburban areas of large cities, demand for land plots and agricultural land purpose, including EVL, have been growing in order to change their intended use for non-agricultural needs and to develop in the future by resale or development.

One of the ways to protect EVL from construction, we offer the economic and legal mechanism of their protection. It includes compensation by the person concerned of the market value of the land plot (estimated as built up) as well as losses of agricultural production caused by the seizure of agricultural land for use for non-agricultural purposes. Such actions will substantially reduce the economic motivation of those who are interested in changing the special purpose of EVL and their development. The formula for calculating the amount of compensation for losses of EVL with a change in their intended use is proposed as follows:

$$
L=M v+\left(A p \times S l \times \frac{B p}{B l} \times K i\right) \times K s
$$

Where $L$ denotes amount of losses of agricultural production after seizure the plot (change of intended use) of EVL, UAH;

$M v$ denotes market value of the land with EVL, which is seizured, calculated as the cost of this land for building, UAH;

Ap denotes plot's area of the agricultural land, ha;

$\mathrm{Sl}$ denotes standard of losses of agricultural production, $\mathrm{UAH}$;

$B p$ denotes soil bonitet of the agricultural land plot which have to seizure;

$B l$ denotes soil bonitet of agricultural lands in the Autonomous Republic of Crimea, the Administrative Region, the cities of Kyiv and Sevastopol;

$K i$ denotes the intensity coefficient of agricultural land use (the ratio of the indicator of differential income of the evaluation of arable land of the land valuation district, in which the land plot is allocated, to a similar indicator in the whole Autonomous Republic of Crimea, Administrative Region, cities of Kyiv and Sevastopol);

$K s$ denotes the coefficient that takes into account the integrated index of EVL values in the structure of land in the administrative district.

High compensatory payments for changing the special purpose of valuable land will be an important economic fuse for their urbanization. The funds received as a result of the payment of the corresponding reimbursements should be directed solely to the implementation of measures related to the implementation of land protection.

\section{Conclusions and proposals}

The parts of organizational and legal mechanism for the land use of EVL are as follows: high compensatory payments for their seizure, inventory and monitoring of EVL, the State Register of EVL. This register will become a tool of increased control by the state and the public for the adherence to the special regime for the use of EVL, protection of them from unjustified seizure and change of the intended purpose.

Information about the EVL should be made public on the public cadastral map of Ukraine. This will help to use the information when planning the territory and organizing the rational land use. Publicity of information about EVL will help to limit the "shadow" redistribution of EVL, the implementation of state, self-government and public control over their use and protection.

These measures can increase the competitiveness of EVL, prevent Land-Grabbing and ensure the sustainable development of rural territory. 


\section{References}

1. Golodnaya O., Kostenkov N. (2010). Espessially Valuable and Valuable Agricultural Lands of Primorski Krai Territory. Herald Buryat State Agricultural Academy. V.R. Filippova, 4, 73-78 (in Russian).

2. Kanash O., Martyn A. (2003). Some approaches to compiling regional lists of especially valuable land. Land Management. 4, 45-48 (in Ukrainian).

3. Kanash O. (2001) Basic problems of agricultural land evaluation zoning. Land Management, 4. 35-38 (in Ukrainian).

4. Kanash O. (2009) Especially Valuable Lands: there is construction and real essence. Land Surveying Journal, 2. 44-45 (in Ukrainian).

5. Martyn A. (2011). The problem of sovereign Land Cadastre in Ukraine. Land Management and Cadastre, 3, 33-50 (in Ukrainian).

6. State Committee of Ukraine for Land Resources. On the use, protection and monitoring of valuable land on November 3, 1997 № 55. Internet site: http://www.uazakon.com/documents/date_7b/pg_iynkwl.htm (in Ukrainian).

7. State Committee of Ukraine for Land Resources. On approval of the list of most valuable groups of soils. on October 6, 2003 № 245. Internet site: http://zakon4.rada.gov.ua/laws/show/z0979-03 (in Ukrainian).

8. Nowakowskiy L., Oleshchenko M. (2007). Socio-economic problems of modern land management. Kyiv: Urozhai (in Ukrainian).

9. Dobryak D., Babmindra D. (2006) Ecological and economic principles of land reform in market conditions. Kyiv: Urozhai (in Ukrainian).

10. Dobryak D., Kanash O., Rozumniy I. (2001) Classification and ecologically safe use of agricultural land. Kyiv: Urozhai (in Ukrainian).

11. Tsarenko, A.A., Schmidt, I.V., Tarbaev, V.A. (2017). Actual aspects of cadaster relations in the monitoring system of land and rural areas. Journal of Environmental Management and Tourism, Volume VIII, Spring, 1(17): 116-122. DOI: 10.14505/jemt.v8.1(17).12

12. The Land Code of Ukraine, No. 2768-III, 25, October 2001 Internet site: http://zakon4.rada.gov.ua/laws/show/2768-14 (in Ukrainian).

13. Ievsiukov, T. (2013) Protection of Highly Valuable Land: Experience of Foreign Countries. Land management, cadastre and land monitoring. Volume 3, p. 19-26

14. Loiko P. (2009) Land Use: Russia, the World (View to the Future). Moskow. 332p.

15. Criteria and Indicators to Identify and Map High Nature Value Areas (2008) / K. Hennenberg, U. Fritsche, K.Wiegmann et al. // Joint International Workshop on High Nature Value Criteria and Potential for Sustainable Use of Degraded Lands, Paris, June 30-July 1, http://www.bioenergywiki.net/images/1/1e/OEKO_CI_RSB_2008_Joint_IssuePaper_Criteria_WS_Paris_2008.pdf.

16. Definition, Identification and Monitoring of HNV Farmland in Germany. http://www.bfn.de/fileadmin/MDB/documents/themen/monitoring/Conferenc_Vilm_HNV_ind_final.pdf.

17. Pointereau P. Identification of High Nature Value farmland in France through statistical information and farm practice surveys / Philippe Pointereau, Maria Luisa Paracchini, Jean-Michel Terres et al. // [Електронний ресурс]. - Режим доступу: http://ams.jrc.it/publications/pdfs/JRC_HNV_France.pdf.

18. Prime and Unique farmlands. Agriculture / Jurist.com http://law.justia.com/cfr/title 07/7-6-1.3.6.27.html.

Information about author

Taras Ievsiukov, Dr.Hab. in Economics., Assoc. Prof., Dean of the Faculty of Land Management, National University of Life and Environmental Sciences of Ukraine. Address: 17, Vasylkivska street, Kiev, 03040, Ukraine. phone: +380979088214, e-mail: ievsiukov_t@nubip.edu.ua . Fields of interest: land use management, rational land use land cadastre, land-use planning, land evaluation, mapping. 